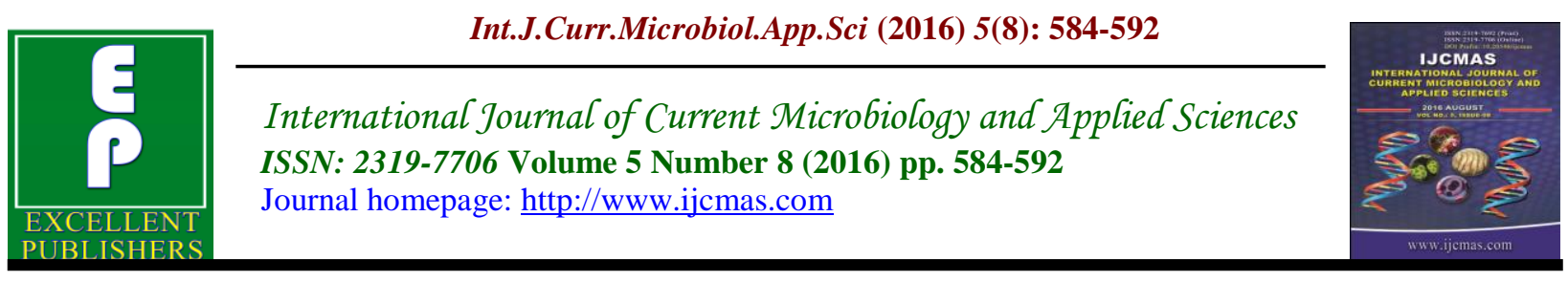

Original Research Article

http://dx.doi.org/10.20546/ijcmas.2016.508.065

\title{
Diversity and Significance of Genus Scenedesmus (Meyen) in River Ganga at Kanpur, India
}

\author{
Vinod Rishi $^{1}$, Sunil Tripathi ${ }^{2}$ and A.K. Awasthi ${ }^{3 *}$ \\ ${ }^{1}$ Department of Botany, Mahatma Gandhi Chitrakoot Gramodaya University, \\ Chitrakoot, Satna, MP, India \\ ${ }^{2}$ ICAR- Indian Institute of Pulses Research, Kanpur, UP, India \\ ${ }^{3}$ Department of Botany, Brahmanand Degree College, Kanpur, UP, India \\ *Corresponding author
}

\begin{abstract}
A B S T R A C T
Keywords

Scenedesmus

(Meyen),

River Ganga.

Article Info

Accepted:

23 July 2016

Available Online:

10 August 2016

Genus Scenedesmus (Meyen), a member of Chlorophyceae, is known for its capability to survive in highly adverse environmental conditions and also good indicator of organic pollution. It is also known as a rich source of protein content. During the present investigation 18 species of Scenedesmus have been identified from different sampling stations of river Ganga at Kanpur. Present study elaborates the diversity and significance of various species of Scenedesmus in the Ganges ecosystem.
\end{abstract}

\section{Introduction}

Algae have the capacity to grow in polluted and unpolluted water and due to this property they are considered to determine the quality of water (Johnston, 1966). They are frequently used for determination of the impact of toxic substances in aquatic ecosystem (Jafari et al., 2006; Léonard et al., 1967). Various algal genera such as Chlorella, Euglena and Scenedesmus etc. are used for the prediction of the degree of pollution i.e. they act as indicator of water quality (Dwivedi et al., 2002; Shukla et al., 1983; Tamura et al., 1958b). Significance of macro and micro algae as a source of food supplement is well known (Burlew , 1953; Biswas, 1953; Borowitzka, 1988; Becker,
1994; Becker , 2007; Clément et al., 1967; Elenkin, 1931; Joubert,1980; Kay, 1991; Klausner, 1986; Sudhaker et al., 1994; Tamura et al., 1958a). Several fresh water and marine algae were usedworldwide by man from long period. Such algae are Chlorella, Ulva, Porphyra, Alaria, Chondrus, Rhodymenia, Codium, Spirulina and Fucus etc. These algae provide full supplements for food such as proteins, carbohydrates, vitamins and minerals etc. The genus Scenedesmus is also rich in protein and considered suitable for such purpose because of its simple structure, small size and easy to cultivate in vitro (Prescott, 1982).The S. obliquus is an ideal 
source for fish feed like Trichogoster faciatus and Puntius ticto (Gupta et al., 1964) and other fish (Das et al., 1967). The genus has been a good indicator of high organic pollution.

\section{Materials and Methods}

The algal samples from different sampling stations (Bithoorghat, Ranighat, Sarsaiyaghat, Golaghat and Jajmaughat) between Bithoor to Jajmau have been collected at monthly interval during a period from June 2009 to May 2010 and simultaneously preserved into 5\% Formalin solution. The Camera Lucida diagrams were prepared for measurement and identification of different taxa present in samples was done by using standard and relevant literature (Okamura, 1913; Trivedi, 1986). The periodicity and succession of different species of Scenedesmus have also been observed.

\section{Results and Discussion}

\section{Systematic Enumeration}

Chlorophyta

Chlorococcales

Scenedesmaceae

Scenedesmus Meyen, 1829

S. abundans (Kirchner) Chodat. Tiffany and Britton, 1952, P 123, Pl 35, Fig 366; Prescott, 1982, P 274, Pl 61, Fig 21.

Colony composed of 2-4 oval or oblong cells arranged in a linear series. Terminal cell s contains 1 or 2 polar and 2 spines at lateral walls. The inner cells have a single spine at each pole. Diameter 4-6.5 $\mu$ and 6$11 \mu$ long (Pl.2, Fig. 1).

S. abundans var. brevicauda G. M. Smith. Prescott, 1982, p 274, Pl 1, Fig 26, 27.

Cells smaller than typical, spines short and less. Diameter $2.5-4.5 \mu$ and length $5-8 \mu$ (Pl.2, Fig. 2,3).

S. abundans var. longicauda G. M. Smith. Prescott, 1982, P274, PI 61, Fig 4-5.

Cells small with relatively long spines (6$9 \mu)$. Diameter 4-6 $\mu$ and length 6-9 $\mu$ (Pl.2, Fig. 4).

S. acuminatus (Lag.) Chodat. Tiffany and Britton, 1952, P123, Pl 35, Fig 368; Prescott, 1982, P 275, PI 62, Fig 16.

Colony composed of four cells some times 8 cells, arranged in a curved series. Cells with sharp and pointed apices. Diameter 4-6 $\mu$ and length 20-35 $\mu$ (P1.2, Fig. 5).

S. acutiformis Schroeder. Tiffany and Britton, 1952, P123, Pl 35, Fig 356; Prescott, 1982, P 275, Pl 62, Fig 6, 7.

Colony composed of single series of 4 cells (2-8), cells fusiform or elliptical with sharply pointed poles. Inner cells with a single facial longitudinal ridge and outer cells with 2-4 longitudinal ridged. Diameter 6-8 $\mu$ and length 15-20 $\mu$ (Pl.2, Fig. 6).

S. arcuatus (Lemmermann) Tiffany and Britton, 1952, P 123, Pl 35, Fig 371; Prescott, 1952, P 175, PI 62, Fig 8.

Colony composed of 4-16 oblong or ovate cells, arranged in double series, cells without spines, poles rounded. Diameter $5-8 \mu$ and length $9-13 \mu$ (Pl.2, Fig. 8).

S. arcuatus var. platydisca G. M. Smith. Prescott, 1982, P275, Pl 62, Fig 10-12.

Colony composed of 4-8 oblong, elliptical cells arranged in flat manner. Diameter 4.5$7 \mu$ and length $10-15 \mu$ (Pl.2, Fig. 7). 
S. armatus (Chodat) G. M. Smith. Tiffany and Britton, 1952, P122, PI 35, Fig 353; Prescott, 1982, P276, PI 62, Fig 13, 14.

Colony composed of 2-8 cells arranged in a single series or sometimes alternating series. Cells oblong- elliptical but ends broadly rounded. Terminal cells with a single spine at each pole, central cells with a median, incomplete longitudinal ridge. Diameter 4$8 \mu$ and length $10-15 \mu$ (Pl.2, Fig. 9).

S. bijuga (Turpin) Lagerheim. Tiffany and Bitton, 1952, P 123, Pl 35, Fig 371; Prescott, 1982, P276, Pl 63, Fig 2, 7.

Colony composed of 2-8 cells arranged in a single series or sometimes in alternating flat series, cells ovate or oblong without spines. Diameter $4-7 \mu$ and length $10-15 \mu$ (Pl.1, Fig. $1)$.

S. bijuga var. alternans (Reinsch). Tiffany and Britton, 192, P123, Pl35, Fig 372; Prescott, 1982, P277, Pl 63, Fig 3, 4.

Cells oval or elliptical arranged in two alternating series. Diameter 5-8 $\mu$ and length 10-15 $\mu$ (Pl.1, Fig. 2).

S. brasiliensis Bohin. Prescott, 1982, P277, PI 63, Fig 5-6.

Colony composed of 2-8 sub-cylindrical, ovate or elliptical cells, arranged in a single series, apices of cells with 1-4 short teeth and with a longitudinal median ridge between the apices of each cell. Diameter 5$7 \mu$ and length $10-20 \mu$ (Pl.1, Fig. 3).

S. dimorphus (Turpin) Kuetzing. Tiffany and Britton, 1952,P123, PI 35, Fig 270; Pescott, 1982, P277, Pl 63, Fig 8,9.

Colony composed of 4-8 fusiform cells, arranged in a single row or alternating row, the inner cells with straight sharp apices, the outer cells lunate and strongly curved with acute apices. Diameter 3-6 $\mu$ and length 15$20 \mu$ (Pl.1, Fig. 4).

S. longus var. Naegelii (de Brebission)G.M. Smith. Prescott, 1982, P279, Pl 63, Fig 24.

Colony composed of 8 cylindrical cells, arranged in a single row, outer cells have long curved spine at each pole, inner cells with a long spine at one pole. Diameter 8$12 \mu$ and length $20-25 \mu$ (Pl.2, Fig. 10).

S.obliquus (Turpin) Kuetzing. Tiffany and Britton, 1952, P122, PI 35, Fig 369; Prescott, 1982, P279, PI3, Fig 17.

Colony composed of 4-8 fusiform cells, arranged in a single row, apices apiculate, and wall smooth. Diameter $4-9 \mu$ and length

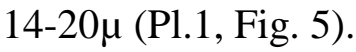

S. quadricauda (Turpin) Breb. Tiffany and Britton, 1952, P122, Pl 35, Fig 357; Prescott, 1982, P280, PI64, Fig 2.

Colony composed of 2-4-8 oblong, cylindrical cells, arranged in a single row, outer cells with a long curved spine at each pole, inner cells without spines. Diameter 5$15 \mu$ and length $20-35 \mu$ (Pl.1, Fig. 6).

S. quadricauda var. longispina (Chodat). G. M. Smith.Prescott, 1982, P280, Pl62, Fig22.

Colony composed of 4-8 oblong, cylindrical cells, arranged in a single row, outer cells with a long spine $(7-10 \mu)$ at each pole. Diameter $3-5 \mu$ and length $8-11 \mu$ (Pl.1, Fig. 7). 
Table.1 Seasonal variation of different species of Genus Scenedesmus (Meyen) from different sampling stations of River Ganga at Kanpur during June, 2009 to May, 2010.

\begin{tabular}{|c|c|c|c|c|c|c|c|c|c|c|c|c|c|c|c|c|}
\hline & \multirow[t]{2}{*}{ Species } & \multicolumn{3}{|c|}{ Site I } & \multicolumn{3}{|c|}{ Site II } & \multicolumn{3}{|c|}{ Site III } & \multicolumn{3}{|c|}{ Site IV } & \multicolumn{3}{|c|}{ Site V } \\
\hline & & $\mathbf{S}$ & $\mathbf{R}$ & $\mathbf{W}$ & $\mathbf{S}$ & $\mathbf{R}$ & $\mathbf{W}$ & $\mathbf{S}$ & $\mathbf{R}$ & $\mathbf{W}$ & $\mathbf{S}$ & $\mathbf{R}$ & $\mathbf{W}$ & $\mathbf{S}$ & $\mathbf{R}$ & $\mathbf{W}$ \\
\hline 1 & Scenedesmus abundans & + & - & + & - & + & + & + & + & + & - & - & - & + & + & + \\
\hline 2 & S. abundans var. brevicauda & - & - & - & + & - & - & - & - & - & + & - & + & + & + & + \\
\hline 3 & S. abundans var. longicauda & + & - & + & - & - & - & + & + & + & - & - & - & - & - & - \\
\hline 4 & S. acuminatus & - & - & & + & - & + & - & - & + & - & - & - & + & - & + \\
\hline 5 & S. acutiformis & - & - & - & - & - & + & - & - & - & - & - & + & + & - & + \\
\hline 6 & S. arcuatus & - & - & - & + & - & -- & + & - & - & + & + & + & - & - & - \\
\hline 7 & S. arcuatus var. platydisca & - & - & - & + & - & + & - & - & - & + & - & - & + & - & + \\
\hline 8 & S. armatus & - & - & + & - & - & - & - & - & + & + & - & + & - & - & - \\
\hline 9 & S. bijuga & - & - & - & - & - & + & + & - & - & + & + & + & + & + & + \\
\hline 10 & S. bijuga var.alternans & + & - & - & + & - & + & + & - & + & - & - & - & + & - & + \\
\hline 11 & S. brasiliensis & - & - & - & - & - & - & - & - & - & - & - & + & - & - & + \\
\hline 12 & S. dimorphus & + & - & + & - & - & - & + & - & + & + & + & + & - & - & - \\
\hline 13 & S. longus var. Naegelii & - & - & - & + & + & + & - & - & - & + & - & + & + & - & + \\
\hline 14 & S. obliquus & - & - & - & - & - & - & + & + & - & + & & + & - & - & - \\
\hline 15 & S. quadricauda & - & - & - & - & - & + & + & - & - & - & - & - & + & - & + \\
\hline 16 & S. quadricauda var. longispina & + & - & + & - & - & - & - & - & - & + & - & - & + & + & + \\
\hline 17 & S. quadricauda var. quadrispina & - & - & - & - & - & - & - & - & - & + & - & + & + & + & + \\
\hline \multirow[t]{2}{*}{18} & S. quadricauda var. Westii & - & - & - & - & - & - & + & - & + & - & - & - & + & - & + \\
\hline & Total & \multicolumn{3}{|c|}{06} & \multicolumn{3}{|c|}{10} & \multicolumn{3}{|l|}{11} & \multicolumn{3}{|c|}{12} & \multicolumn{3}{|c|}{13} \\
\hline
\end{tabular}

(Abbreviation: Site I= Bithoorghat; Site II= Ranighat; Site III= Sarsaiyaghat; Site IV= Golaghat; Site V= Jajmaughat; S=Summer, R=Rain, W=Winter; + = Present; - = Rare or Absent)

Table.2 Comparative study of Protein content from different sources

\begin{tabular}{|c|c|c|}
\hline Source & Percent & References \\
\hline Scenedesmus & $47-66 \%$ & 10 \\
\hline Aphanizomenon & $60 \%$ & 15 \\
\hline Spirulina & 65 to $71 \%$ & \multirow{9}{*}{12} \\
\hline Chlorella & $58 \%$ & \\
\hline Beef & $24-27 \%$ & \\
\hline Chicken & $24 \%$ & \\
\hline Fish & $18-29 \%$ & \\
\hline Wheat & $13 \%$ & \\
\hline Eggs & $13 \%$ & \\
\hline Rice & $3 \%$ & \\
\hline Potatoes & $3 \%$ & \\
\hline
\end{tabular}



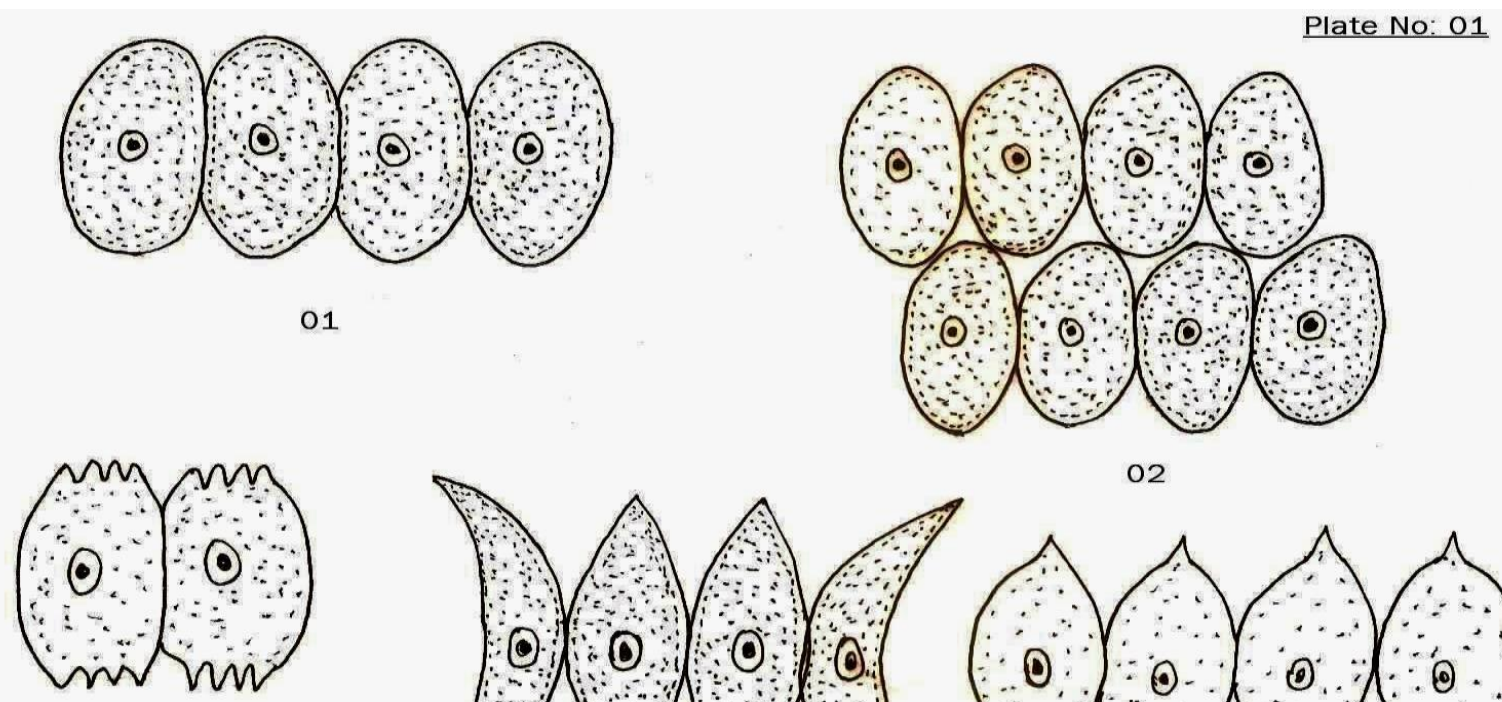

03
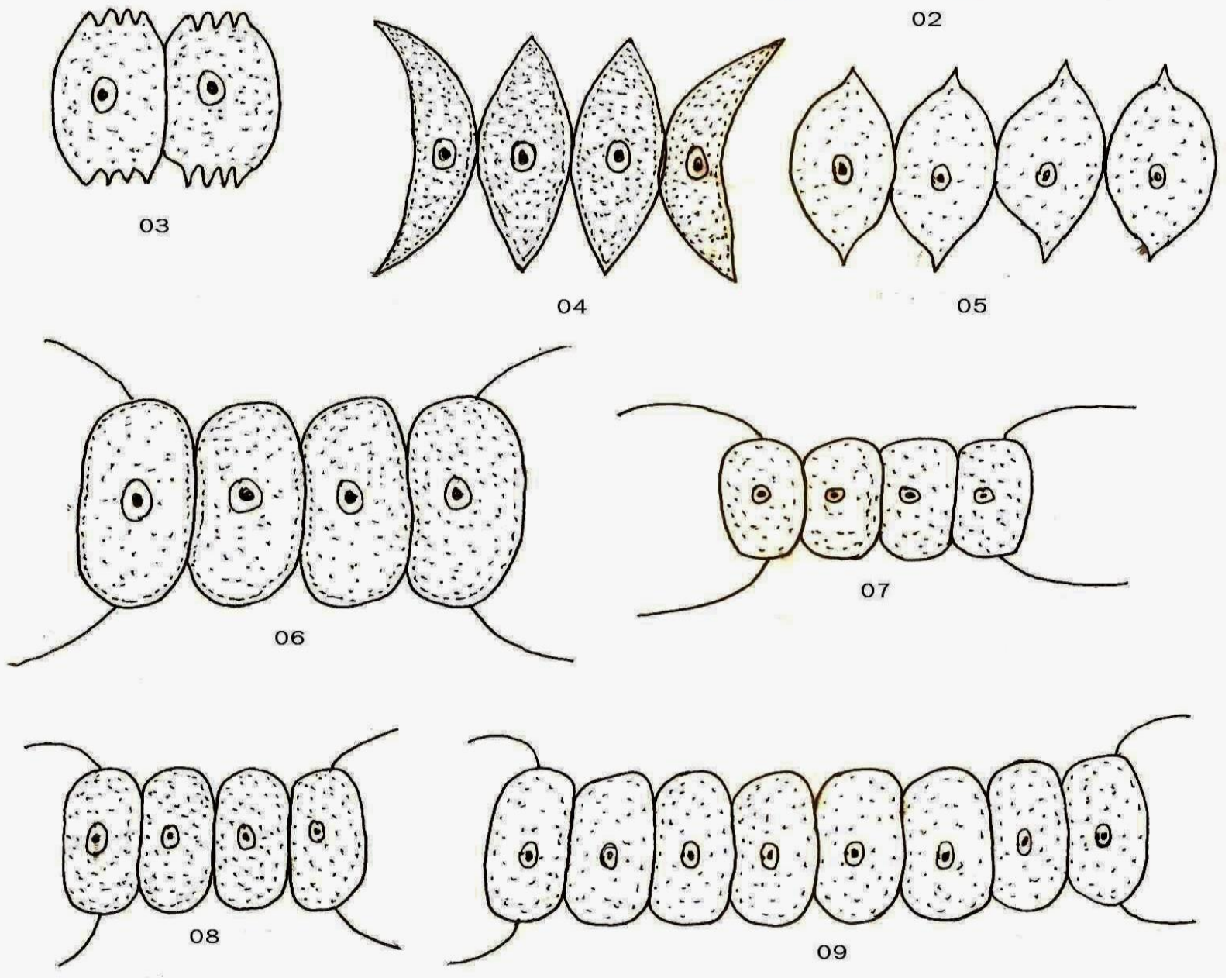

Plate 1

Figures: S. bijuga (1), S. bijuga var. alternans (2), S. brasiliensis (3), S. dimorphus (4), S. obliquus (5), S. quadricauda (6), S. quadricauda var. longispina (7), S. quadricauda var. quadrispina (8), S. quadricauda var. Westii (9). 

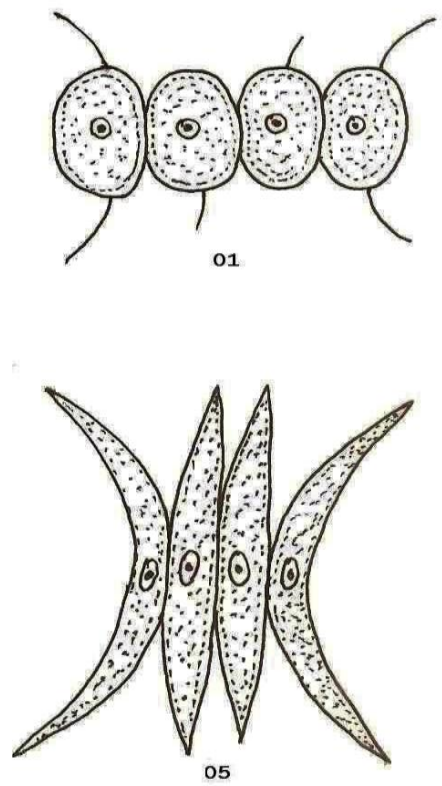

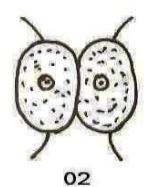

02

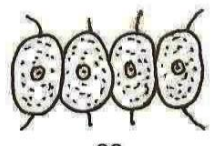

03
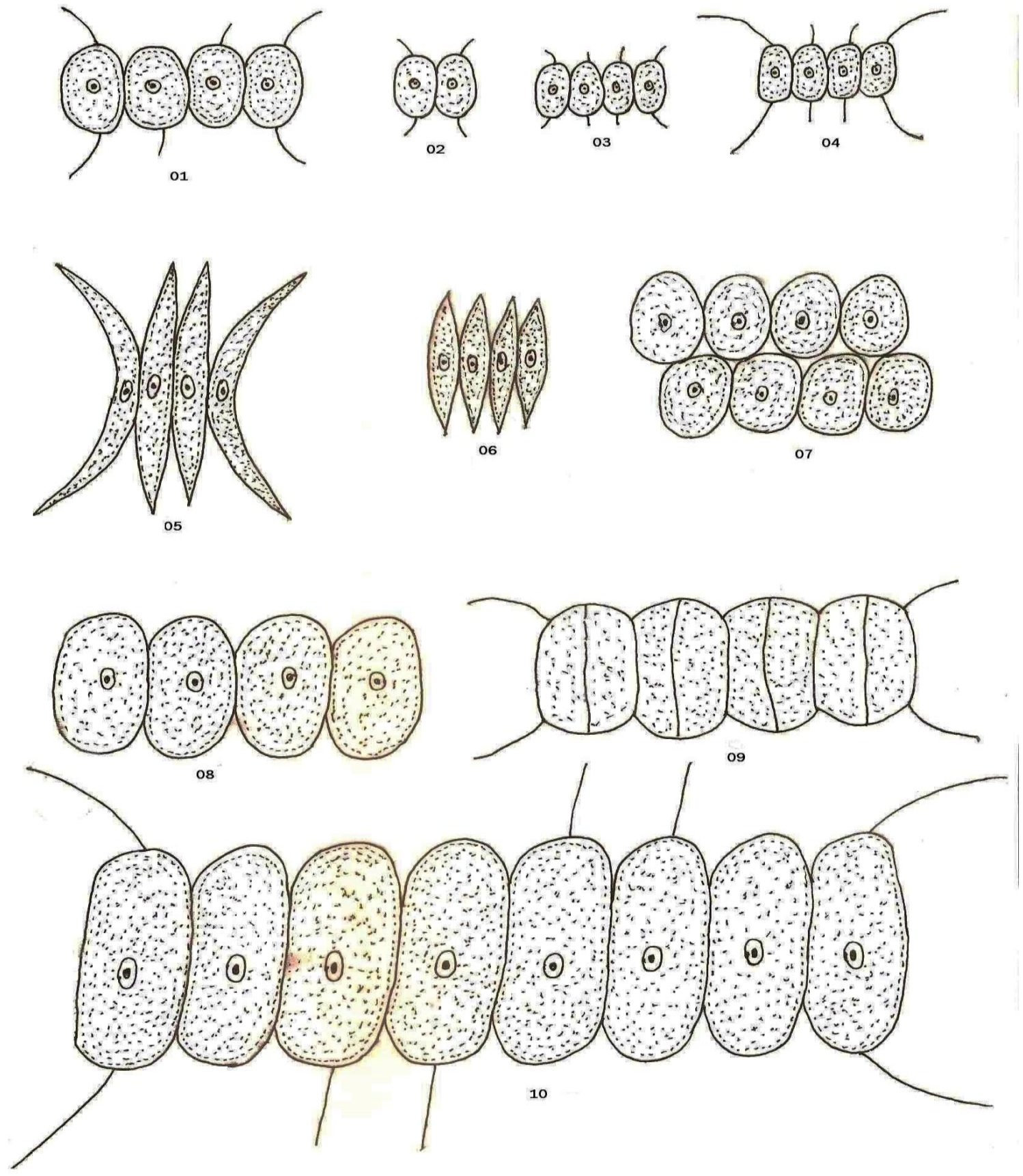

Plate No: 02

Plate 2

Figures: S. abundans (1), S. abundans var. brevicauda (2, 3), S. abundans var. longicauda (4), S. acuminatus (5), S. acutiformis (6), S. arcuatus var. platydisca (7), S. arcuatus (8), S. armatus (9), S. longus var. Naegelii (10). 
Table.3 Comparative chemical composition of some common microalgae $(4,5)$

\begin{tabular}{|l|c|c|c|c|}
\hline Strain & Protein & Carbohydrates & Lipids & Nucleic acid \\
\hline Scenedesmus obliquus & $50-56$ & $10-17$ & $12-14$ & $3-6$ \\
\hline Scenedesmus quadricauda & 47 & - & 1.9 & - \\
\hline Scenedesmus dimorphus & $8-18$ & $21-52$ & $16-40$ & - \\
\hline Chlamydomonas rheinhardii & 48 & 17 & 21 & - \\
\hline Chlorella vulgaris & $51-58$ & $12-17$ & $14-22$ & $4-5$ \\
\hline Chlorella pyrenoidosa & 57 & 26 & 2 & - \\
\hline Spirogyra sp. & $6-20$ & $33-64$ & $11-21$ & - \\
\hline Euglena gracilis & $39-61$ & $14-18$ & $14-20$ & - \\
\hline Spirulina platensis & $46-63$ & $8-14$ & $4--9$ & $2-5$ \\
\hline Spirulina maxima & $60-71$ & $13-16$ & $6-7$ & $3-4.5$ \\
\hline Synechoccus sp. & 63 & 15 & 11 & 5 \\
\hline Anabaena cylindrica & $43-56$ & $25-30$ & $4-7$ & - \\
\hline
\end{tabular}

S. quadricauda var. quadrispina (Chodat) G. M. Smith. Prescott, 1982, P 280, PI 63, Fig 21.

Colony composed of 4-8 oval cells with small spines. Diameter $4-7 \mu, 8-15 \mu$ long and 2-3 $\mu$ long spines (Pl.1, Fig. 8).

S. quadricauda var. Westii G. M. Smith. Prescott, 1982, P 281, Pl 64, Fig. 7, 9.

Colony composed of 4-8 oval cells with broad rounded apices. Diameter $5-8 \mu, 10$ $16 \mu$ long and $2-3 \mu$ long spines (Pl.1, Fig. 9).

The genus Scenedesmus exhibits remarkable seasonal variation in different sampling stations of river Ganga at Kanpur (Table 1). The maximum growth of species were recorded in the months of February, March, April, May and June because in these months the conditions are most favorable for growth and development of the species of genus Scenedesmus . Scenedesmus abundans, S. acuminatus, S. acutiformis, $S$. bijuga, S. obliquus, S. quadricauda, and $S$. dimorphus are good indicators of high organic pollution and also used by fish as food (Prescott, 1982). S. obliquus, $S$. quadricauda, S. dimorphus can be used as food supplement for mankind because they contains high amount of proteins and carbohydrates (Becker, 1994; Becker, 2007). According to Table 2 and 3 the Genus Scenedesmus is a protein rich micro alga. The genus Scenedesmus also have medicinal importance and contains many useful chemicals for treatment of various diseases.

The Scenedesmus sp. has some medicinal and industrial significance also the species having carotenoids (Vitamin A) and $\beta$ carotene act as anticancer agent (Kay, 1991); Vitamin $B_{6}$, riboflavin, nicotinic acid and pantothenate helps in malnutrition; the polysaccharides of Scenedesmus sp. worked as emulsifiers and thickening agent. some species of Scenedesmus contains antitumor agent which may be used in the treatment of tumor (Borowitzka, 1988) and the species of Scenedesmus also have some plant growth regulating substances (Borowitzka, 1988).

The principal objective of this study is to explore the possibilities for the utilization of this green alga as a future food and as medicine for human being and to enhance the further investigations on Scenedesmus sp. 


\section{Acknowledgement}

Authors wish to express their sincere thanks to Dr. Vivek Kumar Dwivedi, Principal, Brahmanand Degree (PG) College, Kanpur for encouragement and facilities to accomplish present work. Authors are also grateful to the University Grant Commission, New Delhi for providing financial assistance as Major Project to the second author and Project Fellowship to the first author.

\section{References}

Becker. 2007. Micro-algae as a source of protein. J. Biotechnol. Adv., 25(2): 207-210.

Becker, E.W. 1994. In "Microalgae: biotechnology and microbiology" Ed. Baddiley, J. et al., 178 Cambridge Univ. Press, Cambridge, New York.

Biswas, K. 1953. The algae as substitute food for human and animal consumption. Sci. and Cult., 19(5): 246-249.

Borowitzka, M.A. 1988. Vitamins and fine chemicals from microalgae. In: Borowitzka MA and Borowitzka LJ (eds) Microalgal Biotechnology. Cambridge University Press, New York, 153-196.

Burlew, John, S. 1953. Current status of the large-scale culture of algae. In: Algal Culture: From laboratory to pilot plant, pub. 600. Carnegie Institution of Washington, Washington, D. C., p. 3.

Clément, G., Giddey, C. and Menzi, R. 1967. Amino acid composition and nutritive value of the alga Spirulina maxima. J. Sci. Fd. Agric., 18(11): 497-501.

Das, O.A.K., Shukla, A.C. and Gupta, A.B. 1967. Ichthyologica, 4(1-2): 50-52.

Dwivedi, B.K. and PANDEY, G.C. 2002. Physicochemial factors and algal diversity of two ponds (Girja Kund and Maqubara pond) Faizabad, India. Poll. Res., 21(3): 361-369.

Elenkin, A.A. 1931. On some edible freshwater algae. Priroda, 20: 964991.

Gross, R., Schoeneberger, H., Gross, U. 1986. The nutritional quality of Scenedesmus acutus in a semiindustrial plant in Peru. J. Environ. Pathol. Toxicol. Oncol., 6(5-6): 47-57.

Gupta, A.B. and Ahmad, M.R. 1964. Effect of algal hormones on the growth and development of rice seedlings. $L a b$ dev. J. Sci. Tech., 2(3): 203. http://www.naturalways.com.

Jafari, N.G. and Gunale, V.R. 2006. Hydrobiological study of algae of an urban freshwater river. J. Appl. Sci. Environ. Mgt., 10(2): 153-158.

Johnston, H.W. 1966. The biological and economic importance of algae. Part 2. Tuatara, 14(1): 30-63.

Joubert, G. 1980. A bioassay application for quantitative toxicity management using green algae, Selenastrum capricornutum. Water Res., 14:17591763.

Kay, R.A. 1991. Microalgae as Food and Supplement. Critical Reviews in food Science and Nutrition, 30(6):555-573 by CRC Press Inc. (Aphan)

Klausner, A. 1986. Algal culture food for thought. Biotechnol., 4(11): 947.

Léonard, J. and Compére, P. 1967. Spirulina platensis (Gom.) Geitl., a blue alga of high food value because of its richness in proteins. Bull. Jard. Bot. Nat. Belg. 37(1): Suppl., 23 p.

Namikawa, S. 1906. Freshwater algae as an article of human food. Bull. Coll. Agric. Tokyo univ., 7: 123-4.

Okamura, K. 1913. On Chinese edible Nostoc (Fahtsai) identified by Prof. Setchell as Nostoc commune var. flagelliforme. Bot. Mag. Tokyo, 27: 177-183. 
Palmer, C.M. 1969. A composite rating of algae tolerating organic pollution. $J$. Phycol., 5: 78-82.

Philipose, M.T. 1967. Chlorococcales. ICAR, New Delhi.

Prescott, G.W. 1982. The algae of western great lake area. Otto Koeltz Science Pub. D-6240 Koenigstein/ WGermany. 272-281.

Shukla, B.K., Shukla, A.C. and Trivedi, P.S. 1983. A contribution to Genus Scenedesmus. All India Appl. Phyco. Cong., Kanpur, 244-250.

Spoehr, H.A. 1951. Chlorella as a source of food. Proc. Am. Phil. Soc., 95: 62.

Sudhaker, G., Joyothi, B., Venkateswarlu, V. 1994. Role of diatoms as indicator of polluted gradients. Environ. Monit. \& Assess., 33:85-99.

Tamura, E., Baba, H., Nishihara, A., Isobe, S., Matsuno, N. and Tamura, A. 1958a. Nutritional studies on Chlorella, report 5. Nutrient components and amino acid composition of de colored Chlorella and Scenedesmus. Annual Report of The National Institute of Nutrition, Toyamacho, Tokoyo, Japan, p. 20.

Tamura, E., Baba, H., Tamura, A., Matsuno, N., Kobatake, Y. and Morimoto, K. 1958b. Nutritional studies on Chlorella, report 11. Human experiment on absorption of decolored Scenedesmus. Ibid. p. 31.

Tiffany, L.H. and Britton, M.E. 1952. The algae of Illinois. Uni. Of Chicago press Chicago, 1-406.

Trivedi, R.K. 1986. Role of algae in biomonitoring of water pollution. Asian Environ., 8(3): 31-42.

\section{How to cite this article:}

Vinod Rishi, Sunil Tripathi and A.K. Awasthi. 2016. Diversity and Significance of Genus Scenedesmus (Meyen) in River Ganga at Kanpur, India. Int.J.Curr.Microbiol.App.Sci. 5(8): 584-592. doi: http://dx.doi.org/10.20546/ijcmas.2016.508.065 